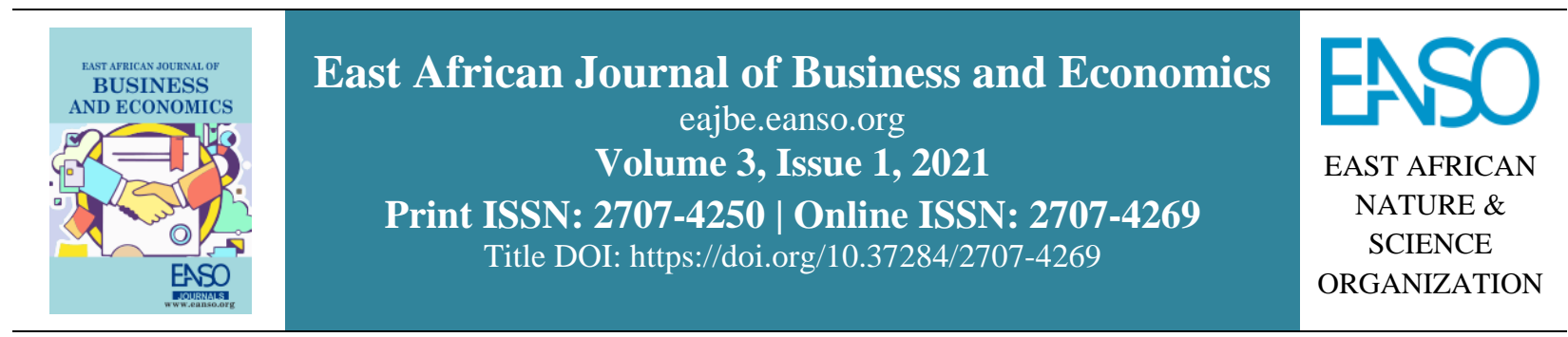

Original Article

\title{
Improving Sustainable Development of Eco-Tourism in Kenya.
}

\author{
Edwin Otieno Ogweno ${ }^{1 *}$ \\ ${ }^{1}$ Maasai Mara University, P. O. Box 861 - 20500 Narok, Kenya. \\ *Correspondence email: edierhymez@gmail.com.
}

Article DOI: https://doi.org/10.37284/eajbe.3.1.327

\section{Date Published: ABSTRACT}

13 May 2021 Eco-tourism is generally defined as the type of tourism that involves visiting a natural environment without interfering with its habitat. The tourism industry

Keywords: is a multibillion-dollar industry that continues to expand and evolve around

Sustainable Development, the world, however, to achieve sustainable growth, it requires a shift in Economic Development, Opportunities, Pollution,

Eco-Tourism. planning and as a result, more focus on eco-tourism. When thinking of tourism, one thinks of a certain group of people visiting a particular destination for sightseeing, holiday vacations, and to have a good time; while that could be true, tourism touches on more than that. The tourism sector, besides just the gratification and exchange of culture, also involves environmental aspects, social aspects, and sustainability. As the world strives to achieve long-term growth targets in the sustainable development goals, eco-tourism continues to receive much attention. Eco tourism has been related to programs for sustainable development in protected areas, community-based conservation organizations, and in many aspects aimed at achieving sustainable development goals on environmental and habitat protection. In order to sustainably improve the eco-tourism sector, there is a need for continuous education, a supportive policy environment, and more research on the sector.

\section{APA CITATION}

Ogweno, E. O. (2021). Improving Sustainable Development of Eco-Tourism in Kenya. East African Journal of Business and Economics, 3(1), 98-103. https://doi.org/10.37284/eajbe.3.1. 327

\section{CHICAGO CITATION}

Ogweno, Edwin Otieno. 2021. "Improving Sustainable Development of Eco-Tourism in Kenya:.”. East African Journal of Business and Economics 3 (1), 98-103. https://doi.org/10.37284/eajbe.3.1. 327

98 This work is licensed under a Creative Commons Attribution 4.0 International License. 


\section{HARVARD CITATION}

Ogweno, E. O. (2021) "Improving Sustainable Development of Eco-Tourism in Kenya.”, East African Journal of Business and Economics, 3 (1), pp. 98-103. doi: 10.37284/eajbe.3.1. 327.

\section{IEEE CITATION}

E. O. Ogweno, "Improving Sustainable Development of Eco-Tourism in Kenya.", EAJBE, vol. 3, no. 1, pp. 98-103, May. 2021.

\section{MLA CITATION}

Ogweno, Edwin Otieno. "Improving Sustainable Development of Eco-Tourism in Kenya.". East African Journal of Business and Economics, Vol. 3, no. 1, May. 2021, pp. 98-103, doi:10.37284/eajbe.3.1.327

\section{INTRODUCTION}

Tourism, as we understand it is the movement of a person or people out of their usual places of stay to a certain destination for a period for either business or leisure purposes (Leiper, 1979).

Sustainable tourism however is environmentally and culturally responsible and shares similar concepts to eco-tourism, green travel, fair trade, and ethical travel. The most preferred definition for this concept if by the World Tourism Organization that defines sustainable tourism as;

Tourism that leads to the management of all resources in such a way that economic, social, and aesthetic needs can be fulfilled while maintaining cultural integrity, essential ecological processes, biological diversity, and life support systems (WTO, 2020).

The term "eco-tourism" refers to tourism focused on preserving natural areas in order to aid conservation efforts. Richard Sharpley (2006) argues that ecotourism is reliant on visitors behaving responsibly and environmentally appropriate during the entire eco-tourism journey, including the pre- and posttrip phases. Eco-tourists seek out and consume environmentally friendly tourism experiences, which sets them apart from normal or mass tourists. This paper discusses the scope of eco-tourism and its challenges in the Kenyan context.

\section{Definition of Ecotourism}

The word "eco-tourism" refers to any form of tourism that is considered to be environmentally friendly. The International Ecotourism Society (2015) uses the following definition to define ecotourism:
Responsible travel to natural areas that conserves the environment sustains the wellbeing of the local people and involves interpretation and education.

Eco-tourism encompasses environmental, economic, and community concerns. The ecological aspect of eco-tourism means that it contributes to the protection of nature, the economic aspect means that it is a tool for a sustainable economy, and the community aspect means that eco-tourism empowers the community by giving local citizens positions in eco-tourism and increasing their participation in conservation while also embracing the community's diverse culture.

\section{Components of Eco-tourism}

Nature appreciation, ecological sustainability, environmental education, local profit, and tourist satisfaction are the five key components of ecotourism values. (Murugan, 2007).

\section{Nature Appreciation}

Eco-tourism focuses on the natural environment's physical, biological, and cultural characteristics. All eco-tourism definitely hinges on a natural environmental feature. This could be a forest, or the sea and the animals and the ecosystem around these natural features. Most eco-tourism focuses on one or more components of nature including the flora, the fauna or the liths. Fauna in this scenario refers to the animal species that are mostly targeted like the elephant and the whale, while flora mostly refers to the plant species. Liths are natural formations like mountains and other physical geographic features that are of interest.

The planning, development, and management of eco-tourism require the protection of natural resources.

99 | This work is licensed under a Creative Commons Attribution 4.0 International License. 


\section{Sustainability Ecologically}

Eco-tourism is a form of tourism that is environmentally friendly and begins in a natural setting. Any country or region's eco-tourism challenge is to increase tourism potential and product quality without adversely impacting the ecosystem that sustains and protects it. This entails making sure that the type, site, and intensity of ecotourism do not harm natural settings as all tourism should be environmentally, socially, and economically sustainable. One of the best-case scenarios where sustainable ecological eco-tourism has occurred is in Turkey where the government made a conscious move towards eco-tourism.

In Turkey, in the Tourism Strategy of Turkey-2023 and the Ninth Development Plan (2007-2013), the government developed plans and regulations aimed at leveraging Turkey's natural, cultural, and geographical values in order to diversify Turkey's tourism portfolio from just tourism, to include ecotourism in order to preserve the country's unique natural settings. Though eco-tourism implementation is still low, the government of Turkey has seen a tremendous rise in sustainable eco tourism and as a result, activities like sea kayaking tours, land-based ecotourism, and bicycle touring/mountain biking have been introduced, resulting in increased benefits (Kiper, 2013).

\section{Environmentally Educative}

Eco-educational component is a key feature in ecotourism that distinguishes it from other types of nature-based tourism. Environmental education and explanation are critical components of a rewarding and meaningful eco-tourism experience. Tourists who want to interact with the environment in order to improve their understanding, experience, and knowledge of it are drawn to eco-tourism. As a result, eco-tourism can hopefully result in constructive environmental action and increased conservation awareness. Eco-tourism education has the potential to influence tourist, culture, and industry behaviour, as well as promote the longterm sustainability of tourist activity in natural areas. Natural resource management needs education as well. Tourists can benefit from this learning by seeing the big picture of the environment as it considers the community's environmental and cultural values, as well as other topics including resource management.

\section{More Beneficial for Local}

Getting involved with local communities helps not only the community and the environment, but also the tourist experience. Eco-tourism operations and the provision of information, resources, facilities, and goods can involve local communities. The benefits of eco-tourism to the host community and the climate outweigh the costs. In addition to social and cultural benefits, eco-tourism can generate revenue for resource conservation management. The contribution may be funded with a part of the cost of the tour, helping to subsidize a conservation initiative. On the other hand, it could provide onthe-ground support, with visitors participating in environmental data collection and/or analysis.

Werfenweng in Austria has been used time and again as one of the major examples of successful eco-tourism sites where the communities living there have been fully integrated in the eco-tourism approach. In Werfenweng with only a community of approximately 1000 people, the community has been engaged in multiple eco-tourism activities right from coming up with innovations of using carbon free mobility to tour the place to acting as guides and providing vital information about the community and tourism sites and attraction. This community also benefits from eco-tourism through the soft-mobility initiative which offers rewards and discounts to its residents too including provision of discounts on eco-friendly travel options ( Sustainability Leaders Project, 2020).

\section{Tourist's Satisfaction}

Tourist satisfaction with the eco-tourism experience is critical to the eco-tourism industry's long-term viability. The value of visitor safety in terms of political stability is included in this concept. Information regarding eco-tourism opportunities should accurately represent what is available at ecotourism destinations. The ecotourism experience should meet or exceed the guest's fair expectations. Client satisfaction and service should come in second only to the preservation and protection of the places they visit.

\section{$100 \mid$ This work is licensed under a Creative Commons Attribution 4.0 International License.}




\section{ECO-TOURISM IN KENYA}

For over a century, Kenya's sandy shorelines, breathtaking views, and amazing wildlife have pulled in tourists to the country. However, this has been hit with challenges including environmental pollution as a result of tourist's transportation needs, tourist littering, poaching, and game hunting. These activities caused a negative impact on tourist attractions causing a decline in the flora and fauna and destruction of local tourist attraction sites.

Fortunately, the 'gospel' of eco-tourism had arrived in Kenya by the late 1990s. Since then, the country has seen a progressive trend toward more aggressive environmental protection initiatives, as well as practices that prioritize low-impact activities that preserve natural attractions.

Eco-tourism in Kenya has evolved from an abstract idea to a niche-driven market that attracts both repeat and new customers. Although some tourist destinations combine conventional tourism with more environmentally friendly practices, others market themselves as unique eco-tourism destinations.

\section{Eco-tourist Sites in Kenya case Examples}

Kenya has a diverse eco-tourism profile with over 100 eco-tourism sites (Burdett, 2018). The Maasai Mara national reserve was founded in 1961 and has since earned a reputation as one of Kenya's and the world's best eco-tourism destinations. Traveling around Kenya and staying in an eco-rated hotel is a great way to help environmental and natural resource protection efforts that are part of the ecotourism agenda. Some of the key eco-tourist sites that have really exemplified eco-tourism include:

\section{The Murera Springs Eco Lodge}

Murera Springs is a tourist lodge at the foot of Mount Kenya that has been artistically built. All of the site's electricity is produced by solar panels, and the cuisine is made from locally grown vegetables, with the wastewater being recycled and used to irrigate the grasses and gardens around the lodge. The lodge is located next to Meru National Park, which is a popular tourist destination in East Africa.
This region's past is intertwined with conservation efforts. (Mwongela, 2010).

\section{Maji Moto Eco Camp}

Maji Moto Eco Camp, located near Diani, is another notable eco-tourism project that benefits both the environment and the local community. All of the structures at Maji Moto, which are run by Maasai, were constructed in the Maasai style, with only local materials including branches, stalks, grass, cow dung, and stone (no trees were felled for construction). The camp has no electricity, and water for showers is carried in from a nearby hot spring, so there is no need for heating. (Maji Moto Maasai Cultural Camp, 2020).

\section{The Bamburi Nature Trail}

In Mombasa's Haller Park, the Bamburi Nature Trail is a small wildlife sanctuary that was created from a former limestone quarry and cement factory. It features a crocodile sanctuary, a reptile park with massive tortoises, and a spot to feed giraffes, and is a fantastic attraction for bird lovers, game animals, and extraordinary trees. Visitors can take guided tours through the Bamburi Forest. (Twenidad, 2014).

\section{The Lewa Conservancy}

The Lewa Conservancy, in the foothills of Mount Kenya, provides a similar service on a much larger scale. Elephants, giraffes, buffalo, antelopes, lions, cheetahs, and leopards share this 55,000-acre sanctuary with some of Africa's most endangered animals, including the black rhino and the Gravy's zebra. Lewa also holds an annual wilderness marathon to raise awareness and funds for wildlife conservation efforts. (Szapary, 2000).

\section{LOCAL SUPPORT FOR ECO-TOURISM IN KENYA}

Kenyans are overwhelmingly supportive of ecotourism, not only from the government and individuals, but also from businesses dedicated to saving Kenya's natural resources and enabling nearby communities. The Basecamp Foundation, for example, is a non-profit that works with host communities and partner organizations in Kenya to

101 This work is licensed under a Creative Commons Attribution 4.0 International License. 
create "sustainable destinations," emphasizing the positive effects of tourism can have on the natural, social, and economic aspects of the environment. Eco-tourism Kenya is another agency that devotes a significant portion of its resources to community outreach, extensive research projects, and providing leadership opportunities for local residents.

The Eco-Tourism Society of Kenya (ESOK) launched an eco-rating scheme in 2005, demonstrating Kenya's contribution to sustainable tourism (Burdett, 2018). This system assigns a score to lodgings and camps based on their environmental friendliness. The Eco-Tourism Society of Kenya's website has an inventory of eco-tourist projects.

Kenya was named the number one global destination for eco-tourism in 2003, with the Kenya Tourism Board receiving the award at the American Society of Travel Agents World Congress in Miami. (Mutulu, 2014). Despite things being a long time ago, the niche continues to grow and gain popularity as the industry continues to get bigger and bigger.

\section{CHALLENGES TO ECO-TOURISM IN KENYA}

Kenyan ecotourism faces several challenges, mostly due to a lack of infrastructural facilities such as roads and lodging, strategic business plans, welltrained nature guides, methods of gaining community consensus and awareness initiatives. (Okech, 2011).

However, as with time and development, the ecotourism sector is constantly facing new challenges, which include:

- Environment and biodiversity threats, such as the extinction of wildlife and endangered plants, habitat loss and degradation

- Coastal disruption, such as shoreline degradation and pollution, as well as the effects on coral reefs and fish spawning grounds

- Deforestation: loss of forests for fuel and timber has an effect on soil and water quality, biodiversity, and local communities' ability to harvest forest products.
- Tourist leisure habits, such as golf courses and swimming pools, have resulted in water overuse.

- Urban problems: Congestion and overcrowding in cities and increased road traffic,have resulted into environmental impacts, such as air and noise pollution, as well as effects on health.

- Contribute to climate change: fossil fuel energy use for transport, hotel, and leisure requirements all exacerbates climate change.

- Unsustainable and inequitable resource use: excessive energy and water use, as well as waste output, are both examples of unsustainable and inequitable resource use that continue to pose a challenge to eco-tourism.

\section{IMPROVING SUSTAINABILITY DEVELOPMENT}

Eco-tourism has been one of the fastest-growing segments of the tourism industry in Kenya, with annual growth rates of 10-15 percent. (Okech, 2011. In order to improve sustainability, the following components need to be taken into consideration:

- Make the best possible use of natural resources, which are a critical component of tourism growth, while also preserving essential ecological forms and contributing to the preservation of common heritage and biodiversity.

- Respect host communities' sociocultural authenticity, maintain their built and living social heritage and traditional values, and contribute to intercultural understanding and tolerance.

- Maintain reasonable, long-term financial operations, providing socioeconomic benefits to all stakeholders. Benefits such as stable employment and income-earning opportunities for host communities and social administrations all contribute to poverty reduction.

102 | This work is licensed under a Creative Commons Attribution 4.0 International License. 


\section{CONCLUSION}

Eco-tourism is defined as "responsible travel to natural areas that conserves the environment and improves the well-being of local people." As stated in this paper, eco-tourism is the way of the future, and eco-tourism will ensure that we are able to meet sustainable development goals. In Kenya, the practice of eco-tourism continues to garner growth and development, with more eco-tourism sites coming up in the country. However, as we saw in the paper, eco-tourism continues to face challenges that could be potentially solved through policy change, community engagement and education and public awareness both for tourists and community members. This paper suggests that more active research needs to be done in the eco-tourism sector as there is a huge gap in local research in the sector.

\section{REFERENCES}

Burdett, M. (2018, May 07). Case study: Ecotourism in Kenya. Retrieved October 25, 2020, from https://geographycasestudy.com/casestudy-ecotourism-in-kenya/

International Ecotourism Society. (2020). What is Ecotourism? Retrieved October 25, 2020, from https://ecotourism.org/what-is-ecotourism/

Kiper, T. (2013, July 01). Role of Ecotourism in Sustainable Development. Retrieved November 22, 2020, from https://www.intechopen.com/bo oks/advances-in-landscape-architecture/role-ofecotourism-in-sustainable-development

Leiper, N. (1979). The framework of tourism. Annals of Tourism Research, 6(4), 390-407. DOI: $10.1016 / 0160-7383(79) 90003-3$

Maji Moto Maasai Cultural Camp (n.d.). Our Camp: Maji Moto Maasai Cultural Camp. Retrieved October 25, 2020, from http://majim otomaasaicamp.com/our-camp/

Murugan, A.,\&; Tudu, S. (2020.). Exploring The Potential And Usefulness Of Ecotourism In Puducherry With Special Reference To Tourism And Environment. Retrieved November 22, 2020, From Https://Www.Academia.Edu/2760 1175/Exploring_The_Potential_And_Usefulnes s_Of_Ecotourism_In_Puducherry_With_Specia
1_Reference_To_Tourism_And_Environment_ Dr_Annamalai_Murugan

Mutulu, F. (2014, September 4). The Rise of Ecotourism in Kenya. Retrieved October 25, 2020, from https://afktravel.com/60170/ecotour ism-kenya/

Mwongela, F. (2010). Murera Lodge goes 'green.' Retrieved October 25, 2020, from https://test.standardmedia.co.ke/homeaway/article/2000025263/murera-lodge-goesgreen

Okech, R. N. (2011). Ecotourism Development and Challenges: A Kenyan Experience. Tourism Analysis, 16(1), 19- 30. DOI:10.3727/1083542 $11 \times 12988225899967$

Sharpley, R. (2006). Eco-tourism: A Consumption Perspective. Journal of Ecotourism, 5(1-2), 722. DOI:10.1080/14724040608668444

Sustainability Leaders Project. (n.d.). Destination Werfenweng, Austria: Sustainable Tourism Strategies, Stories and Examples. Retrieved November 22, 2020, from https://sustainabilityleaders.com/werfenweng-sustainable-tourismexample/

Szapary, P. (2000). The Lewa Wildlife Conservancy in Kenya: A Case Study [Abstract]. Wildlife Conservation by Sustainable Use, 3550. DOI:10.1007/978-94-011-4012-6_4

Twenidad, C. (2014). Reclamation of Bamburi Nature Trails. Retrieved October 25, 2020, from https://www.academia.edu/9621995/Reclamatio n_of_Bamburi_Nature_Trails

WTO. (n.d.). Ecotourism and Protected Areas. Retrieved November 22, 2020, from https://www.unwto.org/sustainable- developme $\mathrm{nt} /$ ecotourism-and-protected-areas

103 | This work is licensed under a Creative Commons Attribution 4.0 International License. 